\title{
Isolation, Structure Elucidation, and Cytotoxic Evaluation of Furanonaphthoquinones from in Vitro Plantlets and Cultures of Streptocarpus dunnii
}

\author{
Helen Sheridan, ${ }^{*}{ }^{\dagger}$ Cora Nestor, ${ }^{\dagger}$ Lorraine O’ Driscoll, ${ }^{\ddagger}$ and Ingrid Hook ${ }^{*}, \dagger$ \\ Natural Product Drug Discovery Group, School of Pharmacy and Pharmaceutical Sciences, Trinity College Dublin, 23 Westland Row, \\ Dublin 2, Ireland, and Cancer Research Group, School of Pharmacy and Pharmaceutical Sciences, Trinity College Dublin, 23 Westland Row, \\ Dublin 2, Ireland
}

Received June 7, 2010

Two new furanonaphthoquinones, (3R)-7-methoxy- $\alpha$-dunnione $(\mathbf{5})$ and (3R)-6-hydroxy-7-methoxy- $\alpha$-dunnione (6), along with the known (3R)-dunnione (1), $(3 R)$ - $\alpha$-dunnione (2), (3R)-7-hydroxy- $\alpha$-dunnione (3), and 1-hydroxy-2-methylanthraquinone (4), were isolated from in vitro cultures of Streptocarpus dunnii. The structures of compounds 5 and $\mathbf{6}$ were established by spectroscopic means. This is the first report of hydroxylated furanonaphthoquinones in a Streptocarpus species. Compounds $\mathbf{1} \mathbf{- 3}$ demonstrated cytotoxic activity against a range of breast cancer and pancreatic tumor cell lines.

Streptocarpus (Cape Primrose) is the largest genus in the Gesneriaceae, a plant family composed mostly of tropical and subtropical herbs, comprising ca. 130 genera and 2900 species worldwide. Many Streptocarpus species are specific in their distribution and occur only in small populations, mainly in Africa. ${ }^{1,2}$ The presence of a number of quinone metabolites in three related species of Streptocarpus, namely, S. dunnii, S. pole-evansii, and $S$. dendiculatus, has been reported. ${ }^{1}$ The major metabolites isolated from these species are furanonaphthoquinones and anthraquinones. ${ }^{3-5}$ Several of these compounds have potent insecticidal and fungicidal activity. ${ }^{6}$ Similar metabolites have been isolated from Calceolaria andina $^{6,7}$ and $C$. integrifolia (Scrophulariaceae). ${ }^{8}$ Recently, hydroxylated derivatives of furanonaphthoquinones have been isolated from Chirita eburnea (Gesneriaceae) and have been shown to have antioxidant activity. ${ }^{9}$

As part of an ongoing drug discovery program, we have been evaluating the minor metabolites produced by Streptocarpus dunnii J.D.Hooker in in vitro grown plantlets and cultures established in our laboratories. Phytochemical analysis of the medium supporting the growth of $S$. dunnii plantlets has led to the isolation and identification of the known furanonaphthoquinones $(3 R)$-dunnione (1), (3R)- $\alpha$-dunnione (2), ${ }^{10}$ and (3R)-7-hydroxy- $\alpha$-dunnione $(3)^{9}$ and the known anthraquinone 1-hydroxy-2-methylanthraquinone (4). ${ }^{3-5}$ Two new metabolites, $(3 R)-7$-methoxy- $\alpha$-dunnione (5) and (3R)-6-hydroxy-7-methoxy- $\alpha$-dunnione (6), have been isolated and characterized. This is the first report of hydroxylated naphthoquinones from Streptocarpus species. Compounds 1-3 demonstrated cytotoxic activity against a range of breast cancer and a pancreatic tumor cell line.

Plantlets of $S$. dunnii were grown in a liquid hormone-free medium. Dried plantlets were subject to Soxhlet extraction sequentially with $n$-hexane, EtOAc, and $\mathrm{MeOH}$, each for $72 \mathrm{~h}$. No compounds of interest were isolated from the resultant extracts. The brightly colored medium was separated from the plantlets and was extracted with EtOAc to yield compounds 1-6. The furanonaphthoquinone ( $3 R$ )-dunnione was isolated as a bright orange solid. The chemical structure and relative configuration of this isolate were confirmed by comparison of its spectroscopic data with known literature values. ${ }^{10}$ The majority of such data were in agreement with those previously reported. However, in the current study, the

* To whom correspondence should be addressed. Tel: (+353)-1-8962825. Fax: (+353)-1-8962804. E-mail: (H.S.) hsheridn@tcd.ie; (I.H.) ihook@ tcd.ie.

Natural Product Drug Discovery Group.

$\div$ Cancer Research Group.
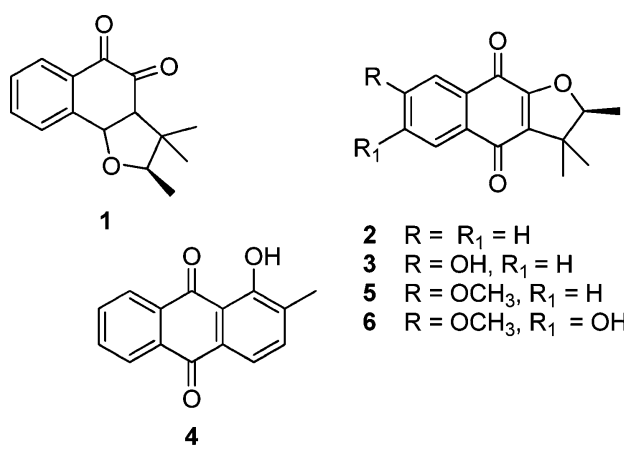

$2 \mathrm{R}=\mathrm{R}_{1}=\mathrm{H}$

$3 \mathrm{R}=\mathrm{OH}, \mathrm{R}_{1}=\mathrm{H}$

$5 \mathrm{R}=\mathrm{OCH}_{3}, \mathrm{R}_{1}=\mathrm{H}$

$6 \mathrm{R}=\mathrm{OCH}_{3}, \mathrm{R}_{1}=\mathrm{OH}$

methyl at $\mathrm{C}-3^{1}$ of $\mathbf{1}$ was clearly and unambiguously assigned in the HMQC spectrum to the doublet at $\delta 14.6$, and consequently $\mathrm{C}-5^{1}$ was assigned to $\delta 25.8$. Literature assignments for this isolate are not consistent with the current HMQC data. The structure of (3R)- $\alpha$-dunnione (2) was confirmed by comparison of the spectral data with known literature values. The majority of the data were in agreement with published values; however as for $\mathbf{1}$, the furan methyl groups diagnostic for $\alpha$-dunnione and its derivatives were reassigned on the basis of HMQC data. The physical and spectroscopic data for the third isolate were consistent with the structure (3R)-7-hydroxy- $\alpha$-dunnione (3), recently isolated from Chirita eburnean, also a member of the plant family Gesneriaceae. ${ }^{9}$ This is the first report of a hydroxylated furanonaphthoquinone from a Streptocarpus species. The known anthraquinone $\mathbf{4}$ was identified by comparison of their spectroscopic and physical properties with literature values. ${ }^{3-5}$

Compound $\mathbf{5}$ was isolated from the $n$-hexane extract as an amorphous, purple solid. The molecular formula was determined to be $\mathrm{C}_{16} \mathrm{H}_{16} \mathrm{O}_{4}$ from the molecular ion peak at $m / z, 272.1011\left[\mathrm{M}^{+}\right]$ in the HREIMS. The ${ }^{1} \mathrm{H}$ NMR spectrum exhibited three methyl signals at $\delta 1.17$ (s), 1.33 (d), and 1.37 (indicative of an $\alpha$-dunnione derivative). The aromatic region of the ${ }^{1} \mathrm{H}$ NMR spectrum exhibited three aromatic signals, suggesting a monosubstituted aromatic system. One proton at $\delta 7.00$ occurred as a singlet. The remaining two protons at $\delta 6.78$ and 7.62 were ortho-coupled doublets. A methoxy signal was observed at $\delta 3.17$. Analysis of the ${ }^{13} \mathrm{C} \mathrm{NMR}$ spectrum showed the isolate contained 16 carbons (Table 1), including a methyl signal at $\delta 48.6$, which corresponded to a methoxy substituent. The placement of the methoxy substituent was determined by the HMBC experiment. From the HMBC spectrum (Figure 1), correlations between the methyl signals at C-4 ${ }^{1}(\delta 20.4)$ and $\mathrm{C}-5^{1}(\delta 25.5)$ and the methine group at $\mathrm{C}-2^{1}(\delta$ 89.9) and the quaternary carbon at $\mathrm{C}-1^{1}(\delta 44.6)$ were observed, thus confirming 
Table 1. NMR Data for (3R)-7-Methoxy- $\alpha$-dunnione (5) and (3R)-6-Hydroxy-7-methoxy- $\alpha$-dunnione (6)

\begin{tabular}{lrrlrlr}
\hline carbon & $\delta_{\mathrm{C}}(\mathbf{6})$ & $\delta_{\mathrm{H}}(\mathbf{5})$ & \multicolumn{1}{c}{ HMBC $(\mathbf{5})$} & $\delta_{\mathrm{C}}(\mathbf{6})$ & \multicolumn{1}{c}{$\delta_{\mathrm{H}}(\mathbf{6})$} & $\mathrm{HMBC}(\mathbf{6})$ \\
\hline 5 & 128.2 & 7.62 & $133.1,169.0,181.0$ & 106.6 & 7.30 & $114.4,126.6,129.2(\mathrm{w}), 157.9,182.6179 .3(\mathrm{w})$, \\
6 & 121.4 & 6.78 & & & \\
8 & 113.8 & 7.00 & $179.3,126.4,169.0$ & 114.0 & 7.10 & $106.6,120.4,126.6,154.9,179.3,182.6(\mathrm{w})$ \\
$2^{\prime}$ & 89.9 & 4.48 & $20.4,25.5$ & 90.3 & $4.49-4.54$ & $19.1,24.5,44.5,129.2(\mathrm{w})$ \\
$3^{\prime}$ & 14.0 & 1.33 & $20.3,44.3,89.9,130.4$ & 12.6 & $1.40-1.42$ & $19.1,44.5,90.3,129.2$ \\
$4^{\prime}$ & 20.4 & 1.17 & $25.5,44.3,89.9$ & 19.1 & 1.25 & $12.6,24.5,44.5,90.3,129.2$, \\
$5^{\prime}$ & 25.5 & 1.37 & $20.4,44.3,89.9,130.2$ & 24.5 & 1.44 & $19.1,44.5,90.3,129.2$ \\
$\mathrm{OCH}_{3}$ & & & & 54.1 & 3.89 & $154.9,157.9(\mathrm{w})$ \\
\hline
\end{tabular}

the presence of a furan ring. These methyl groups also showed correlations to a quaternary carbon at $\delta 130.3$, which could be assigned to C-3. The ortho-coupled proton at $\delta 7.62$ was correlated directly with the carbon at $\delta 128.2$ from the HMQC spectrum. This proton also showed a strong correlation in the HMBC spectrum to the carbonyl at $\delta 181.0(\mathrm{C}-4)$. This was used to place the proton at the $\mathrm{C}-5$ position in the molecule. The proton also showed connectivity to a quaternary carbon at $\delta 133.3$, allowing this carbon to be assigned to C-10. A correlation was also observed between this proton and an oxygenated carbon at $\delta$ 169.0. This confirmed the presence of the substituent on the aromatic ring, but as the proton at C-5 ( $\delta 7.62)$ is ortho-coupled, the oxygenated substituent could not be at the C-6 position, which was assigned at $\delta 121.4$ with the ortho-proton at $\delta 6.78$. The uncoupled proton at $\delta 7.00$ was found to be attached to the carbon at $\delta 113.8$ from the HMQC spectrum; this carbon has been shifted upfield in the ${ }^{13} \mathrm{C}$ NMR spectrum, suggesting this proton to be adjacent to the methoxy substituent. The proton also showed a significant correlation with the carbonyl group at $\delta 179.1$ in the HMBC spectrum, placing the uncoupled proton in the $\mathrm{C}-8$ position beside the carbonyl at $\mathrm{C}-1$. This proton at $\mathrm{C}-8$ also showed a correlation to a quaternary carbon at $\delta 126.4$, which was assigned as C-9. A weak correlation was also observed between the proton at C-8 and the oxygenated carbon at $\delta 169.0$, which placed the oxygenated substituent, a methoxy group, at the $\mathrm{C}-7$ position, identifying the isolate as $(R)-7$-methoxy- $\alpha$-dunnione (5).

The final compound (6) was isolated as a purple, amorphous solid. The molecular formula was determined to be $\mathrm{C}_{16} \mathrm{H}_{16} \mathrm{O}_{5}$ from the molecular ion peak at $\mathrm{m} / \mathrm{z}, 288.0992$ in the HREIMS. The ${ }^{1} \mathrm{H}$ NMR spectrum was similar to that of $\mathbf{5}$. A singlet at $\delta 3.89$, integrating for three protons, was assigned as a methoxy substituent. In the aromatic region of the ${ }^{1} \mathrm{H} \mathrm{NMR}$ spectrum, only two aromatic signals were observed, both of which resonated as uncoupled singlets, suggesting a disubstituted derivative. The ${ }^{13} \mathrm{C} N M R$ spectrum (Table 1) showed the isolate contained 16 carbons. The upfield shift of both of the aromatic $\mathrm{C}-\mathrm{H}$ signals supported the presence of two oxygenated substituents on the aromatic ring. The placement of the substituents was determined by analysis of the HMBC and HMQC spectra. These data established that the isolate is $(R)$-6-hydroxy-7-methoxy- $\alpha$-dunnione (6).

All of the isolated compounds were determined to be optically pure when there were no observed shifts in the NMR resonances when treated with the chiral shift reagent, europium(III) tris[3(heptafluoropropylhydroxymethylene)- $d$-camphorate], $\left(\mathrm{Eu}(\mathrm{hfc})_{3}\right)$. The enantiomeric purity and negative rotations of the newly isolated 5 and $\mathbf{6}$ suggest that these new derivatives have the $R$ configuration. ${ }^{9}$ Compounds $\mathbf{5}$ and $\mathbf{6}$ are new natural products isolated in this study for the first time. This is also the first report of the isolation of

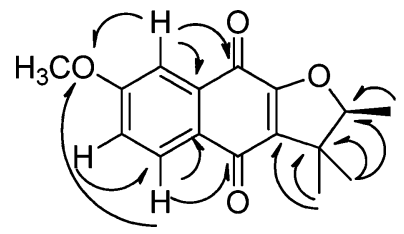

Figure 1. HMBC correlations for $\mathbf{5}$. hydroxylated derivatives of $(3 R)$ - $\alpha$-dunnione from Streptocarpus species. It is interesting to note that in the early studies of in vitro cultures of $S$. dunii no derivatives of $\alpha$-dunnione were identified, ${ }^{3-5}$ while the in vitro cultures generated in this study differ significantly in the production of (3R)-dunnione (1), (3R)- $\alpha$-dunnione (2), and only hydroxylated derivatives of the $\alpha$-dunnione skeleton.

The cytotoxic activity of the isolated compounds $\mathbf{1 - 6}$ was evaluated against a small panel of cancer cell lines. The test panel included three breast cancer cell lines (MCF-7, BT474, Hs578T) and one pancreatic cell line (Mia-Paca-2). The effects of these compounds on the cells are exemplified in Figure 2. MiaPaca-2 cells are adherent, small cells that form cobblestone patterns as the cells become confluent (Figure 2, panel A). Exposure to the isolated compounds resulted in reduced proliferation and induced cell death. The resulting irregularly sized, stretched, stressed cells and detaching cellular bodies are typical of progression to cell death (panels B-D (Figure 2). Considering the breast cancer cell line data only, it is noteworthy that Hs578T, representing a highly aggressive subtype of breast cancer that is responsible for a disproportionate number of breast cancer deaths, is much less sensitive to the furanonaphthoquinones compared to MCF7 and BT474 cells.

The cell lines tested were most sensitive to $\mathbf{1 - 3}$, with 4-6 inactive. Overall, the cell lines were most sensitive to dunnione (1), having $\mathrm{IC}_{50}$ values of $1.0 \mu \mathrm{M}$ in BT474 (breast cancer) and $2.0 \mu \mathrm{m}$ in MiaPaca-2 (pancreatic cell line). The dunnione and $\alpha$-dunnione carbon skeletons confer far greater cytotoxicity in comparison with the anthraquinone skeleton. Substitution at C-7 does not appear to decrease the activity of $\mathbf{3}$ relative to $\mathbf{2}$. However, substitution of the C-7 hydroxyl does decrease cytotoxicity of $\mathbf{5}$ relative to $\mathbf{3}$. We have recently demonstrated that compounds 1-6 also inhibit the development of T-cell polarization with HuT-78 T lymphocytes, which indicates the ability of compounds tested to inhibit the inflammatory response by decreasing LFA-1-mediated T-cell motility. ${ }^{11}$ Combined with the current report, this group of

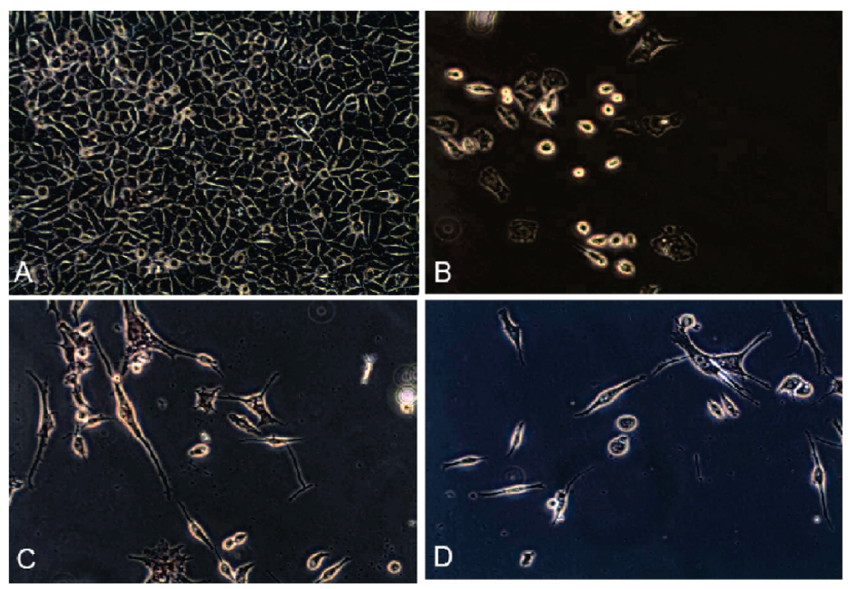

Figure 2. (a) MiaPaca-2; (b) MiaPaca-2 incubated with $2(10 \mu \mathrm{M})$ : (c) MiaPaca-2 incubated with $1(10 \mu \mathrm{M})$ : (d) MiaPaca-2 incubated with $6(20 \mu \mathrm{M})$. 
compounds warrants further evaluation to determine their potential for different forms of cancer.

\section{Experimental Section}

General Experimental Procedures. Melting points were determined on a Me-Opta hot stage and are uncorrected. Infrared spectra were recorded on a Nicolet 205 FT-IR spectrophotometer. Nuclear magnetic resonance spectra (NMR) spectra were recorded using a Bruker Avance 400 instrument. ${ }^{1} \mathrm{H}$ NMR spectra were recorded at $400.13 \mathrm{MHz}$, and ${ }^{13} \mathrm{C}$ NMR spectra were recorded at $75.47 \mathrm{MHz}$. Chemical shifts are given in parts per million (ppm) and were referenced to solvent signals. COSY, HSQC, and HBMC were performed using Bruker microprograms. Spectra were analyzed using MestRec magnetic resonance companion version 4.4.1.0. High-resolution mass spectra were determined on a Micromass LCT instrument operating in $\mathrm{ES}^{+}$mode. TLC was performed on commercially precoated plates (Merck, Kieselgel $60 \mathrm{~F}_{254}$ ). Column chromatography was carried out on Merck Kieselgel 60 [70-230 mesh] (E. Merck, Art 9385, Darmstadt). Visualization was by examination under visible light, UV $(254 \mathrm{~nm})$, and UV (365 nm) or by spraying with anisaldehyde/concentrated sulfuric acid reagent followed by heating for $5-10 \mathrm{~min}$ at $110{ }^{\circ} \mathrm{C}$.

Plant Material. Seeds of Streptocarpus dunnii were received from Silverhill Seeds, Cape Town, South Africa, in January 2003. Identification of germinated plantlets was confirmed by J. Manning, Compton Herbarium, South African National Biodiversity Institute, Cape Town, and a voucher specimen (ID 100907) has been deposited in the TCD herbarium. For disinfection, seeds were washed with absolute alcohol (5 min) prior to surface sterilization with a $15 \%$ commercial sodium hypochlorite solution $(15 \mathrm{~min})$ and rinsed with sterile water. Following sterilization, the seeds were transferred to agar plates containing an agar-solidified micropropagation medium $(20 \mathrm{~mL})$ and sealed with Parafilm. The micropropagation medium contained Murashige \& Skoog basal salts, ${ }^{12}$ sucrose $(30 \mathrm{~g} / \mathrm{L})$, mesoinositol $(100 \mathrm{mg} / \mathrm{L})$, and thiamine $\mathrm{HCl}(0.4 \mathrm{mg} / \mathrm{L})$. Seeds germinated within two weeks were placed in a culture room maintained at $25{ }^{\circ} \mathrm{C}$ on an 18:6 h light:dark cycle.

In Vitro Plants. The sterile germinated seeds (see above) were grown on the solid micropropagation medium in a culture room for eight weeks and allowed to develop into plantlets. The plantlets were separated and grown for a further eight weeks in Petri dishes. After a sufficient size and number of plantlets had been obtained, they were transferred to culture vessels (125 mL Sigma baby food jars) containing the agar solidified micropropagation medium $(50 \mathrm{~mL})$. Some plantlets were also transferred to liquid micropropagation medium $(150 \mathrm{~mL})$ in Erlenmeyer flasks $(250 \mathrm{~mL})$. The plants were maintained by periodic subdivision (8-10 weeks) into liquid or agar-solidified medium. The in vitro plantlets were maintained under light and agitation conditions.

Extraction and Isolation. The orange-red growth medium was kept frozen $\left(-8{ }^{\circ} \mathrm{C}\right)$ until needed and was extracted sequentially with $n$-hexane $(\times 3)$ and ethyl acetate $(\times 3)$. The extracts were concentrated to yield $110.4 \mathrm{mg}(0.0034 \%)$ and $73.4 \mathrm{mg}(0.0024 \%)$ from the $n$-hexane and ethyl acetate residues. The $n$-hexane $(110.4 \mathrm{mg})$ extract was subjected to column chromatography using a solvent gradient of $n$-hexane to EtOAc (100:1 to 70:30). Fractions were collected (10 mL), and fractions $14-16,18-27$, and 30-35 were combined on the basis of TLC. These pooled fractions were subjected to repeated preparative TLC $(\times 4)$ using $n$-hexane-EtOAc $(9: 1)$ as solvent. Bands were removed from the plates, the silica was extracted with EtOAc-MeOH, and solvent was evaporated in vacuo to yield compounds $\mathbf{1 - 6}$.

(3R)-7-Methoxy- $\alpha$-dunnione (5): dark purple, amorphous solid (6.8 $\mathrm{mg}) ;[\alpha]^{25}{ }_{\mathrm{D}}-148$ ( $\left.c 0.09, \mathrm{MeOH}\right) ; \mathrm{UV} \lambda_{\max } 267,308,351,417,438$ nm, IR (film) $v_{\max } 3589,2974,2927,1679,1641,1609,1595,1573$, $1453,1353,1313,1213,1037,925,862 \mathrm{~cm}^{-1} ;{ }^{1} \mathrm{H}$ and ${ }^{13} \mathrm{C}$ NMR spectra (Table 1); EIMS (70 eV) m/z [M+] 272 (25), 244 (100), 215, 201, 199, 188, 141; HREIMS $m / z$ 272.1014, calcd for $\mathrm{C}_{16} \mathrm{H}_{16} \mathrm{O}_{4}, 272.1011$.

(R)-6-Hydroxy-7-methoxy- $\alpha$-dunnione (6): amorphous, purple solid (4.1 mg); $[\alpha]^{25}{ }_{\mathrm{D}}-98$ (c 0.07, MeOH); UV $\lambda_{\max } 278,329,460 \mathrm{~nm}$; IR (film) $v_{\max } 3305,1633,1612,1591,1298,1091 \mathrm{~cm}^{-1}$; ${ }^{1} \mathrm{H}$ and ${ }^{13} \mathrm{C} \mathrm{NMR}$ spectra (Table 1); EIMS (70 eV) $\mathrm{m} / z 288\left[\mathrm{M}^{+}\right](35), 289$ (27) $[\mathrm{M}+$ $1]^{+}, 273(100)\left[\mathrm{M}^{+}-\mathrm{CH}_{3}\right], 260(5)\left[\mathrm{M}^{+}-\mathrm{CO}\right], 245(15)[\mathrm{m} / \mathrm{z}, 273-$ $\left.\mathrm{CH}_{3}\right], 231,218,203,202,188,151,128,115$; HREIMS m/z 288.0997, calcd for $\mathrm{C}_{16} \mathrm{H}_{16} \mathrm{O}_{5}, 288.0992$.

In Vitro Cancer Cell Lines. Three human breast cancer cell lines (BT474, MCF-7, Hs578T) and a pancreatic cancer cell line (MiaPaca2) were obtained from the American Tissue Culture Collection,
Table 2. Cytotoxic Activity of $\mathbf{1 - 6}$ in in Vitro Cancer Cell Lines

\begin{tabular}{ccccc}
\hline compound $^{a}$ & $\begin{array}{c}\text { MCF-7 } \\
\left(\mathrm{IC}_{50}(\mu \mathrm{M})\right)\end{array}$ & $\begin{array}{c}\mathrm{BT} 474 \\
\left(\mathrm{IC}_{50}(\mu \mathrm{M})\right)\end{array}$ & $\begin{array}{c}\mathrm{Hs} 578 \mathrm{~T} \\
\left(\mathrm{IC}_{50}(\mu \mathrm{M})\right)\end{array}$ & $\begin{array}{c}\text { MiaPaca-2 } \\
\left(\mathrm{IC}_{50}(\mu \mathrm{M})\right)\end{array}$ \\
\hline $\mathbf{1}$ & $2.3 \pm 0.6$ & $1.0 \pm 0.5$ & $5.0 \pm 1.3$ & $1.9 \pm 0.4$ \\
$\mathbf{2}$ & $5.8 \pm 0.3$ & $4.5 \pm 0.7$ & $>10$ & $4.6 \pm 0.1$ \\
$\mathbf{3}$ & $5.7 \pm 1.5$ & $4.9 \pm 1.1$ & $>10$ & $6.7 \pm 1.0$ \\
\hline
\end{tabular}

${ }^{a}$ Compounds 4-6 were relatively inactive $\left(\mathrm{IC}_{50}>10 \mu \mathrm{m}\right)$ for all cancer cells used.

Manassas, VA. BT474 and MCF-7 cells were maintained in RPMI1640 medium supplemented with $10 \%$ fetal calf serum (FCS; BioWhittaker, Lonza), Hs578T cells were maintained in DMEM supplemented with $10 \% \mathrm{FCS}$ and $10 \mu \mathrm{g} / \mathrm{mL}$ insulin (Sigma; I-516), and MiaPaca- 2 cells were maintained in DMEM with 5\% FCS. All cell lines were cultured at $37{ }^{\circ} \mathrm{C}$ in $5 \% \mathrm{CO}_{2}$.

Cytotoxicity Assays. For all assays, cells were pretreated in a standard manner to ensure that they were healthy and in a logarithmic phase of growth prior to analysis. Two days prior to the assay, this involved subculturing cells into $75 \mathrm{~cm}^{2}$ flasks at a density of $2 \times 10^{5}$ cells/flask. The following day, the medium was replaced in all flasks. The assay involved plating $100 \mu \mathrm{L}$ volumes of cells, from a singlecell suspension, into 96-well plates at a density predetermined to result in approximately $80 \%$ confluence in seven days under control conditions. Specifically, MCF-7 was seeded at $3 \times 10^{3}$ cells/well; BT474, at $5 \times 10^{3}$ cells/well; Hs578T, at $3 \times 10^{3}$ cells/well; and MiaPaca-2, at $1 \times 10^{3}$ cells/well. Cells were allowed to attach for $24 \mathrm{~h}$ at $37{ }^{\circ} \mathrm{C}$ in $5 \% \mathrm{CO}_{2}$

For all cytotoxicity assays, $100 \mu \mathrm{L}$ of the required compound dilution (see below) was added to each plate, with eight replicate wells set up for each compound concentration. As positive controls, cells in a series of eight replicate wells were exposed to culture medium only and medium containing an equal concentration of DMSO as in the test samples, respectively. Medium only was added to another series of replicate empty wells, to act as blank/negative control. The plates were then incubated for a further six days at $37^{\circ} \mathrm{C}$ in $5 \% \mathrm{CO}_{2}$. Cytotoxicity profiles of compounds were determined by intracellular acid phosphatase analysis. In brief, the medium was removed, the cells were washed twice with $100 \mu \mathrm{L}$ of PBS (Oxoid; BR0014G), and $100 \mu \mathrm{L}$ of assay substrate (10 mM phosphatase substrate (Sigma; P4744) in 0.1 $\mathrm{M}$ sodium acetate [Sigma; S5636), $\mathrm{pH}$ 5.5; $0.1 \%$ Triton-X-100 [(Sigma; $\mathrm{X}-100)]$ was subsequently added to each well. The plates were incubated at $37{ }^{\circ} \mathrm{C}, 5 \% \mathrm{CO}_{2}$ in darkness. After $2 \mathrm{~h}$, the reaction was terminated by the addition of $50 \mu \mathrm{L}$ of $1 \mathrm{M} \mathrm{NaOH}$. The optical density for each well was read at $405 \mathrm{~nm}$ against a reference wavelength of $620 \mathrm{~nm}$. All assays were performed independently a minimum of three times. The $\mathrm{IC}_{50}$ for each compound, in each cell line, was determined using GraphPad Prism Version 5.0. To enable images of cells to be captured, cells were seeded in six-well plates, maintaining the same cell density: surface area and compound concentrations, as for the 96-well assays. Images were captured using an inverted microscope (Olympus CKX41) with Altra Soft Imaging System attachment. Compounds 1-6 were dissolved in DMSO at a final concentration of $10 \mathrm{mM}$. On the day required, a series of concentrations of each compound (prepared as $2 \times$ concentrations so that final concentrations, to which cells were exposed, ranged from 60 to $0.05 \mu \mathrm{M}$ ) were prepared freshly, in the relevant medium for each cell line, for subsequent addition to the cells.

Acknowledgment. We would like to acknowledge Science Foundation Ireland's SRC award to Molecular Therapeutics for Cancer Ireland (award 08/SRC/B1410), which contributed to the determination of biological activity of the isolates.

Supporting Information Available: NMR spectra of compounds 1-6. This material is available free of charge via the Internet at http:// pubs.acs.org.

\section{References and Notes}

(1) Burtt, B. L.; Hilliard, O. M. Streptocarpus, an African Plant Study; University of Natal Press: Pietermaritzburg, South Africa, 1971.

(2) Dibley, R.; Dibley, G. Streptocarpus; Cassell: London, 1995.

(3) Stockigt, J.; Srocka, U.; Zenk, M. Phytochemistry 1973, 12, 23892391. 
(4) Inoue, K.; Ueda, S.; Nayeshiro, H.; Inouye, H. Phytochemistry 1983, $22,737-741$.

(5) Inoue, K.; Ueda, S.; Nayeshiro, H.; Moritome, N.; Inouye, H. Phytochemistry 1984, 23, 312-318.

(6) Khambay, B. P. S.; Batty, D.; Jewess, P. J.; Bateman, G. L.; Hollomon, D. W. Pest Manage. Sci. 2003, 59, 174-182.

(7) Charmy, M. C.; Jimenez, I.; Piovano, M.; Garbarino, J. A.; Didyk, B. Bol. Soc. Chil. Quim. 1995, 38, 187-190.

(8) Ruedi, P.; Eugster, C. Helv. Chim. Acta 1977, 60, 945-947.
(9) Cai, X- H.; Luo, X.-D.; Zhou, J.; Hao, X.-J. J. Nat. Prod. 2005, 68, 797-799.

(10) Inoue, K.; Ueda, S.; Nayeshiro, H.; Moritome, N.; Inouye, H. J. Chem. Soc., Chem. Commun. 1982, 993-997.

(11) Sheridan, H.; Hook, I.; Nestor, C.; Coppins, J.; Ehrhardt, C.; Frankish, N. Planta Med 2008, 74, 1383-1387.

(12) Murashige, T.; Skoog, F. Physiol. Planta 1962, 15, 473-497.

NP100358A 